\title{
"AOS PÉS DOS PRETOS E PRETAS QUITANDEIRAS": EXPERIÊNCIAS DE TRABALHO E ESTRATÉGIAS DE VIDA \\ EM TORNO DO PRIMEIRO MERCADO PÚBLICO \\ DE DESTERRO - 1840-1890*
}

Fabiane Popinigis $^{*}$

$\mathrm{E}$

m 1851 foi inaugurado o prédio do primeiro Mercado Público de Desterro, capital da província de Santa Catarina. Num movimento que também estava ocorrendo em outras regiões, sua construção já vinha sendo aventada e discutida desde a década de 1830, fosse em virtude dos embates e ajustes entre as funções das Câmaras Municipais e as Assembleias Provinciais que viriam a predominar no debate político durante as duas décadas seguintes, ou em decorrência da suposta necessidade de sanear e "embelezar" pontos centrais das cidades. ${ }^{1}$ Ao acompanhar tais discussões e a posterior construção do

\footnotetext{
Este texto é um resultado do estágio pós-doutoral na UFSC - Universidade Federal de Santa Catarina, que não seria possível sem o financiamento do CNPq. Agradeço imensamente a Beatriz Mamigonian e Henrique Espada Lima pela interlocução e pelas preciosas indicações de fontes e documentos, a Cristiana Schettini e Leonardo Pereira, pela leitura atenciosa do texto e aos pareceristas da Afro-Ásia pelas sugestões e críticas.

* Professora adjunta da Universidade Federal Rural do Rio de Janeiro.

1 Valter Martins, Mercados urbanos, transformações na cidade: abastecimento e cotidiano em Campinas, 1859-1908, Campinas: Editora da Unicamp, 2010; Richard Graham, Feeding the City: From Street Market to Liberal Reform in Salvador, Brazil, 1780-1860, Austin: University of Texas Press, 2010; Juliana Barreto Farias, "Mercado em greve: protestos e organização dos trabalhadores da Praça das Marinhas, Rio de Janeiro/século XIX", Anais do XIX Encontro Regional de Historia: poder, violência e exclusão, ANPUH/USP, São Paulo, 8-12 de set. de 2008. Cd-Rom.
} 
prédio do Mercado, este artigo tem dois objetivos principais. O primeiro é o de revelar e analisar, a partir dos livros de receita e despesa da Câmara Municipal, a grande presença africana nas ruas da pequena Desterro, concentrada nos ramos do comércio ambulante, e, além disso, uma predominância de mulheres exercendo essas funções até meados da década de 1850. Em segundo lugar, retoma-se aqui o problema da construção da memória política da cidade a partir dos posicionamentos sobre a construção do Mercado e das disputas pela reconfiguração da ocupação de espaços centras da cidade em meados da segunda metade do século XIX, considerando a participação ativa de africanos e africanas e seus descendentes como agentes dessa disputa.

Situada entre o Rio de Janeiro e a Bacia do Prata, a capital da província de Santa Catarina, além de sua função estratégica de ocupação e proteção do litoral, era uma das principais praças de comércio do sul do Brasil. De Desterro saíam para outros pontos do litoral brasileiro, principalmente o Rio de Janeiro, os produtos produzidos nas redondezas. Ali aportavam inclusive navios estrangeiros, embora em número muito menor do que os nacionais. ${ }^{2}$

Em 1855, Nossa Senhora do Desterro era uma pequena cidade portuária com 5.611 habitantes, dos quais cerca de 1.436 eram escravos (25\%). ${ }^{3} \mathrm{Em} 1872$, de acordo com o primeiro censo realizado durante o Império, o total de habitantes dessa freguesia urbana subira a 8.608, dentre os quais 1.122 escravos $^{4}(13 \%)$. Percebe-se, portanto, que a diminuição do percentual escravo de $25 \%$ para $13 \%$ da população está mais relacionada ao aumento da população livre do que a uma drástica diminuição do número de escravos.

No núcleo central da freguesia urbana de Nossa Senhora de Desterro estavam concentradas as principais construções da cidade, o Palácio do Governo, a Igreja Matriz, a Câmara Municipal, e, a partir de 1851, o primeiro Mercado Público de Desterro. A Rua do Príncipe era a

Laura Machado Hübener, O comércio da cidade de Desterro no século XIX, Florianópolis: Editora da UFSC, 1981, p. 35.

3 "Mappa aproximado da População da Província de Santa Catharina". Relatório do Presidente da Província, 1855.

4 Rescenseamento de 1872 , p. 1. 
principal rua de comércio varejista, por isso também chamada Rua do Comércio, depois Altino Corrêa e hoje Conselheiro Mafra. A Rua Augusta, que hoje leva o nome de João Pinto, concentrava o comércio atacadista. ${ }^{5}$ As ruas do centro eram iluminadas com lampiões a azeite de peixe, que em 1860 subiram ao número de cem. ${ }^{6}$

A Ilha de Santa Catarina, que abrangia outras freguesias além de Desterro, contava então com 25.709 habitantes, dos quais 2.940 (11\%) eram cativos. ${ }^{7}$ Nas freguesias do interior da Ilha, desenvolviam-se atividades agrícolas e mercantis. Entre elas estavam a de Nossa Senhora de Santo Antônio, no norte, e Ratones, por onde tambem escoava-se os produtos do lado oeste da Ilha para o centro da cidade, tanto pelos caminhos internos quanto pelo rio, em pequenas embarcações. ${ }^{8}$ A Freguesia de Nossa Senhora da Lapa do Ribeirão, quase toda agrícola, era o principal núcleo populacional do sul da Ilha. Ali cultivava-se a mandioca, a cana, o milho, o feijão e o café, e abastecia o núcleo urbano de Desterro com aguardente, farinha e açúcar. ${ }^{9}$ Na Freguesia de Nossa Senhora da Conceição da Lagoa, no meio da Ilha, os habitantes se dedicavam a indústria do peixe e a produção da farinha de mandioca, do açúcar, do melado, além do cultivo de uma diversidade de plantas e alimentos, como mandioca, cana, milho e amendoim. ${ }^{10}$ Pequenas embarcações ligavam o interior da Ilha ao núcleo urbano de Desterro, para desembarcar na praça do mercado e em outras localidades a produção daquelas Freguesias. $^{11}$

Na praça do mercado os habitantes do pequeno núcleo urbano da primeira metade do século XIX, punham em dia suas conversas, faziam seus negócios e, principalmente, abasteciam-se. Havia muito que as

Eliane Veras da Veiga, Florianópolis, memória urbana, Florianópolis: Fundação Cultural de Florianópolis Franklin Cascaes, 2008, p. 64.

6 Oswaldo Cabral, Nossa Senhora do Desterro. Notícia I, Florianópolis: Lunardelli, 1971.

7 Rescenseamento de 1872, p. 125.

8 "Ratones" e "Santo Antônio" em Virgílio dos Reis Várzea, Santa Catarina: a ilha, Florianópolis: IOESC, 1984.

9 Várzea, Santa Catarina: a ilha, "A Cana" e "O Alambique".

10 Várzea, Santa Catarina: a ilha, "Lagoa".

11 Várzea, Santa Catarina: a ilha; e Clemente Gentil Penna, "Escravidão, liberdade e os arranjos de trabalho na Ilha de Santa Catarina nas últimas décadas de escravidão (1850-1888)"

(Dissertação de Mestrado, Universidade Federal de Santa Catarina, 2005), p. 54. 
canoas atracavam na praia de frente à praça. ${ }^{12}$ Lavradores do continente, mas também das demais freguesias da Ilha, vinham trazer seus produtos - como provavelmente fez, décadas depois, o "preto liberto Lourenço Carlos da Cunha" que possuía cento e trinta e dois metros de terras situados de frente para o mar na Caiera da Barra do Sul. Em 1882 Lourenço, que provavelmente não tinha outros herdeiros, lavrou documento doando a propriedade e o que havia nela a uma mulher livre e seus quatro filhos, não sem garantir que ele mesmo tivesse o usufruto do lugar e de sua estrutura enquanto vivesse..$^{13}$ Ali havia uma chácara, um moinho de moer milho e duas canoas, o que certamente dava a Lourenço muitas possibilidades de inserção na economia da Ilha e de garantir sua sobrevivência e a dos seus, através da venda, por ele mesmo ou por seus beneficiários, daqueles gêneros produzidos na dita chácara no Mercado Público de Desterro.

Quem, ao contrário de Lourenço, não possuía as tais canoas podia estar em maus lençóis para escoar a produção, dependentes da possibilidade de transportá-la por terra até a praça do mercado - que, como vimos, concentrava as vendas para o centro urbano muito antes da construção do prédio do Mercado Público propriamente dito. Em 1843, a crer na choradeira da Câmara Municipal pedindo à presidência da província fundos para obras públicas, o caminho entre a freguesia de Santo Antônio - caracterizada pela "grande abundância de gêneros e mantimentos" - e a várzea de Ratones, estava intransitável. Além de privar a cidade de seus produtos, a situação causava outro inconveniente:

Privados os lavradores desses lugares da condução dos gêneros de sua produção a freguesia de Santo Antônio, pelo mau estado da estrada de que se trata e donde as poderiam remeter para o mercado da cidade, vêem-se obrigados a vendê-los aos atravessadores, ou antes, aos monopolistas, que em lanchas pelo Rio de Ratones as vão comprar à porta, impondo-lhes o preço: resultando daí, primeiro, que os lavradores não tiram do seu trabalho o lucro que trariam se pudessem trazer à freguesia

${ }^{12}$ Cabral, Nossa Senhora do Desterro Notícia I, p. 79.

13 Escritura de doação que faz o preto liberto Lourenço Carlos da Cunha a Leopoldina Francisca Allano e seus quatro filhos de nome Floriano, Joaquim, Bento e Manoel, como abaixo se declara. Cartório do Ribeirão da Ilha, livro 12, 1881-1882, Fls. 31v-33. 
e à cidade, os seus gêneros; segundo, que o consumo, principalmente na cidade, os paga a esses especuladores por um preço muito superior ao que pagaria ao lavrador, se as trouxesse à venda. ${ }^{14}$

Era de grande importância, portanto, chegar ao mercado para conseguir um bom preço para os alimentos - coisa que nem todos conseguiam fazer. Por conta disso, o mercado configurava-se como centro de uma rede de relações sociais e comerciais que incluía produtores, pequenos comerciantes, negociantes e distribuidores, além dos consumidores. É através dele, por isso, que podemos tentar entender tais relações e seus sujeitos: tanto o modo pelo qual o espaço foi organizado e os agentes que nele puderam se inserir, quanto às transformações ocorridas com a inauguração do primeiro Mercado Público de Desterro.

\section{A historiografia sobre Santa Catarina e lugar dos africanos}

Além da escassez de trabalhos sobre o Mercado Público ${ }^{15}$, a principal dificuldade para a compreensão das redes sociais constituídas ao seu redor é a falta de atenção dos estudiosos para a presença, em tais espaços, de trabalhadores negros, libertos ou escravos. Nas páginas de livros como Mercado - do mané ao turista, de Ricardo Mesquita, aparecem como sujeitos únicos desse processo os colonos alemães - que, nos conta o livro, com muita perseverança lograram vencer todas as dificuldades para chegar ao Mercado Público com seus produtos antes da construção da ponte Hercílio Luz, que desde 1926 liga a Ilha ao continente e os imigrantes açorianos ${ }^{16}$ Concomitante à apresentação dos resultados de sua pesquisa sobre o Mercado Público, Mesquita desfila feitos de catarinenses "ilustres" acentuando toda a positividade do progresso da cidade. Maravilhas como o avião, a geladeira e o telefone são apresentadas aos leitores no intuito de convencê-los de que as dificuldades,

${ }^{14}$ Arquivo Histórico Municipal de Florianópolis (daqui para frente AHMF), Registro do Relatório da Câmara, ao Ex. ${ }^{\mathrm{mo}} \mathrm{S}^{\mathrm{nr}}$ Presidente da Província. Registro da Correspondência da Câmara Municipal, 1840/1843, $\mathrm{n}^{\circ} 85$.

15 Nivaldo Jorge Silva, A descoberta do Mercado Público, Florianópolis: Associação dos Comerciantes e Varejistas do Mercado Público, 1996; Ricardo Moreira de Mesquita, Mercado do mané ao turista, Florianópolis: edição do autor, 2002.

16 Mesquita, Mercado - do mané ao turista, p. 30. 
a pobreza e a rusticidade foram deixadas para trás, num processo "evolutivo" quase natural. Nesse modelo, parece que as experiências das populações afro-descendentes também teriam tido o mesmo destino, e sua presença na cidade poderia, assim, ser simplesmente apagada.

Nesse sentido, a construção e o modo de funcionamento do segundo Mercado Público, construído e inaugurado durante a década de 1890, são apresentados pelo autor como o apogeu do processo modernizador pelo qual estaria passando a capital da província, e depois, do Estado de Santa Catarina. Em suma, guiando-se pelo livro descuidadamente poder-se-ia imaginar que, à exceção do ilustre poeta simbolista e ex-caixeiro Cruz e Souza, os descendentes africanos não fizeram parte deste processo. ${ }^{17}$ Se a imigração europeia e os marcos de chegada dos imigrantes europeus estão registrados, o mesmo não se pode dizer sobre o tráfico de escravos e a presença de africanos na Ilha e no entorno do Mercado Público.

Em obra do historiador Oswaldo Cabral publicada no início da década de 1970, a presença dos escravos e da população pobre em geral nos arredores do Mercado Público não é mitigada, mas tratada com preconceito e descaso a partir de conflitos registrados nos jornais:

O Mercado da Praça, pelo ajuntamento, em suas imediações, das pessoas mais brutas da cidade - escravos, carregadores, vendeiros, pombeiros, marinheiros, soldados - sempre foi lugar de badernas, algumas simples acertos de contas resolvidos a tapa, outras mais sérias, solucionadas à faca... ${ }^{18}$

A curiosa associação entre "vagabundos", "mendigos" e "pretos vadios", em ajuntamentos que obviamente eram compostos basicamente de trabalhadores "escravos, carregadores, vendeiros, pombeiros, marinheiros, soldados", aos quais ser referiu Cabral, foi uma tendência que,

17 Interessante notar que o poeta simbolista Cruz e Souza, um dos exemplos de "mobilidade social" de homens de cor na sociedade escravista, parece seguir também o estereótipo dessa possibilidade através das ocupações do comércio. $C f$. Comunicação de Elizabete Maria Espíndola, "Cruz e Sousa: modernidade e mobilidade social em Desterro das últimas décadas do século XIX", $3^{\circ}$. Encontro Escravidão e Liberdade no Brasil Meridional. Florianópolis: UFSC, 2007.

18 Oswaldo Cabral, Nossa Senhora do Desterro - Memória I, Florianópolis: edição do autor, 1972, pp. 195-97. 
como em outras partes do Brasil, persistiu de meados da segunda metade do século XIX até chegar ao seu auge durante a Primeira República.

Entretanto, um olhar mais cuidadoso revela que os termos "vagabundo" e "vagabundagem", quando utilizados na imprensa do período, dificilmente se referiam ao não-trabalho desses homens ou mulheres, e sim à sua autonomia e mobilidade. Inicialmente a historiografia sobre a Primeira República tendeu a associar a força dessas categorias, no final do XIX e início do XX, à ideia de "transição" do trabalho escravo para o trabalho livre, e à necessidade de disciplinar e controlar os trabalhadores livres numa nova ordem (capitalista e republicana). ${ }^{19}$ Trabalhos mais recentes mostraram que, em geral, a associação a essas categorias - pela imprensa, ou por representantes dos poderes públicos e até empregadores particulares - estava ligada a diversos outros fatores, sobretudo às ocupações temporárias ou autônomas, moradias incertas e à dificuldade de controle que essas camadas de trabalhadores pobres impunham às autoridades pela sua própria autonomia. ${ }^{20}$

No caso de Desterro, as quitandeiras, apesar do serviço prestado, são frequentemente citadas como estorvo, ou ao menos como presença desagradável e destoante da imagem de cartão postal que homens como o Marechal Antero Ferreira de Brito, presidente da província de Santa Catarina entre $1841^{21}$ e $1848,{ }^{22}$ tinham em mente para as capitais das

19 Essa bibliografia é vasta para o Rio de Janeiro. Conferir principalmente a análise de Sidney Chalhoub sobre o conceito de "classes perigosas" em Trabalho, lar e botequim. O cotidiano dos trabalhadores no Rio de Janeiro da Belle Époque, Campinas: Editora da Unicamp, 2001 [1986]; e Martha de Abreu Esteves, Meninas perdidas: os populares e o cotidiano do amor no Rio de Janeiro da Belle Époque, Rio de Janeiro: Paz e Terra, 1989. Para uma revisão mais completa dessa bibliografia conferir: Fabiane Popinigis e Cristiana Schettini, "Empregados no comércio e prostitutas na formação da classe trabalhadora carioca", ArtCultura, v.11, n.19 (2009), pp. 57-74. No caso de Florianópolis, o tema foi abordado com ênfase na ideia de reajustamento social e normatização dos costumes. Cf. Hermetes Araújo, "A invenção do litoral, reformas urbanas e reajustamento social na $1^{\text {a }}$. República" (Dissertação de Mestrado, Pontifícia Universidade de São Paulo, 1989); e As decaídas - prostituição em Florianópolis (1900-1940), Florianópolis: Ed. da UFSC, 2004.

20 Para um balanço sobre a questão, ver Fabiane Popinigis, Proletários de casaca - trabalhadores no comércio carioca (1850-1911), Campinas: Ed. da Unicamp, 2007.

${ }^{21}$ Fala que o Presidente da Província, o Brigadeiro Antero José Ferreira de Brito dirigiu à Assembleia Legislativa da mesma Província, por ocasião da abertura de sua sessão ordinária em $1^{o}$. de março de 1841, disponível em http://brazil.crl.edu/bsd/bsd/u902/000002.html, acessado em 27/1/2011.

22 Despedida de Antero Ferreira de Brito em: Fala que o Presidente da Província de Santa Catarina, 
províncias do Império. Em 1842, o dito presidente chegou a atribuir o que considerou como os baixos índices de criminalidade de Santa Catarina ao número relativamente pequeno de escravos no total da população. ${ }^{23}$ Por isso, seis anos depois, no relatório de 1848, ele sugeriu que se acabasse com o imposto (mísero) de $5 \$ 000$ réis sobre cada escravo que saísse de Santa Catarina e que, ao contrário, fosse oferecido o prêmio de $10 \$ 000$, ao proprietário, para cada escravo vendido para fora "para cá nunca mais voltar". ${ }^{24}$ Se podemos enxergar em seu ato o germe da visão que até hoje predomina a respeito da ausência de população afrodescendente no Estado, é possível também ver nele um forte indício da importância da escravidão na cidade naquele momento.

Assim, foi a posteriori que os desejos de embranquecimento dos contemporâneos foram corroborados por uma certa historiografia que construiu a ideia de uma província mais branca e europeia do que o resto do país. A proporção da população africana e afro-descendente da Ilha, em comparação com as de outras capitais e centros ligados à agricultura de exportação, como o Rio de Janeiro ou Salvador, foi utilizada por esta historiografia para desconsiderar a importância do trabalho escravo na região. Enfatizou-se a prevalência de pequenas unidades de produção agrícola e a produção daquelas unidades como de subsistência, sem grande relevância para o modelo explicativo da grande plantation escravista voltada para a exportação. ${ }^{25}$ Além disso, a caracterização da utilização da mão de obra escrava como predominantemente do tipo doméstico constituiu-se em argumento essencial para que

o marechal de campo Antero José Ferreira de Brito dirigiu á Assembleia Legislativa da mesma província, no ato de abertura de sua sessão ordinária em $1^{\circ}$. de março de 1848. Santa Catharina, na Typ. Provincial da Cidade do Desterro, 1848. Disponível em http://brazil.crl.edu/ bsd/bsd/935/, acessado em 27/1/2011.

23 Fala que o Presidente da Província de Santa Catariana, o Marechal de Campo Graduado Antero José Ferreira de Brito dirigiu à Assembleia Legislativa de mesma Província na abertura de sua sessão ordenada em $1^{\circ}$. De maio de 1842, fls.10. Disponível em http://brazil.crl.edu/ bsd/bsd/929/000012.html, acessado em 27/1/2011.

${ }^{24}$ Fala que o Presidente da Província de Santa Catariana, o Marechal de Campo Graduado Antero José Ferreira de Brito dirigiu à Assembleia Legislativa da mesma Província na abertura de sua sessão ordenada em $1^{\circ}$. De março de 1848, fls.07. Disponível em http:// brazil.crl.edu/bsd/bsd/935/000009.html, acessado em 27/1/2011.

${ }^{25}$ Cf. Fernando Henrique Cardoso, Negros em Florianópolis: relações sociais e econômicas, Florianópolis: Insular, 2000, 63-77. 
se considerasse seu papel secundário na economia da Ilha. ${ }^{26} \mathrm{~A}$ argumentação em torno dessas características ganhou tal força na historiografia relativa à Santa Catarina - juntando-se a isso a importância de colônias de imigrantes europeus, que teriam alavancado a prosperidade econômica e, mais tarde, o desenvolvimento industrial -, que tomou ares de modelo interpretativo. ${ }^{27}$

No caso catarinense, em conexão com a construção da imagem de sua condição periférica no país, o desenvolvimento e a expansão do comércio, no século $\mathrm{XX}$, foram tratados por certos autores como o apanágio do progresso, o motor da modernização, da produção e do consumo e, como tal, oposto ao atraso da escravidão. O progresso visto como positividade é uma explicação provável para os lamentos a respeito do atraso industrial de Santa Catarina em relação a outras regiões brasileiras. ${ }^{28}$ Por outro lado, a inexistência das grandes plantações de café e cana-de-açúcar juntamente com a imigração europeia, em particular, alemães e italianos, foi, uma das razões para a criação do mito da desimportância da escravidão e de uma presença não significativa de escravos e negros libertos na província em geral. ${ }^{29}$

${ }^{26}$ Nas palavras de Cardoso: "Entretanto, em nenhuma outra atividade os escravos foram mais largamente aproveitados do que nos serviços domésticos. Cidade pobre, centro de uma região em que o desenvolvimento econômico durante o período escravocrata foi pequeno, a escravidão em Desterro e na Ilha foi sobretudo doméstica”, Cardoso, Negros em Florianópolis, p. 12; e "Nenhum outro tipo de atividade, nem a lavoura, absorvia nesse período mão-de-obra escrava mais numerosa (conforme se pode verificar pelo quadro da pagina 118). Foram estes os setores de atividade que permitiram, e alguns exigiram, a existência de negros em Desterro e o aproveitamento regular da mão-de-obra escrava. O ritmo de desenvolvimento econômico desses diversos setores de atividade, já analisados, nos permite compreender a razão da participação relativamente pequena do negro no coeficiente total da população da cidade e da Ilha, que se traduz pelos números que passamos a analisar." Cardoso, Negros em Florianópolis, p. 122.

27 Cardoso, Negros em Florianópolis, pp. 90-1. Para uma crítica detalhada dessas abordagens conferir Penna, "Escravidão, liberdade e os arranjos de trabalho na Ilha de Santa Catarina".

${ }^{28}$ O comércio, segundo Laura Machado Hübener, aquele das grandes exportações e do acúmulo de capital, investimento na produção e em infraestrutura, foi ínfimo, insuficiente para desenvolver significativa atividade industrial. As grandes lavouras de café, ou os engenhos de cana-de-açúcar, não tiveram lugar na formação social e econômica da província de Santa Catarina. Nem mesmo o principal produto de exportação, a farinha de mandioca, teria trazido possibilidades de acumulação, embora o período da Guerra do Paraguai fosse visto como responsável por um pequeno "boom" na economia catarinense, sobretudo os anos de 1868 a 1870. Cf. Laura Machado Hübener, O comércio da cidade do Desterro no século XIX, Florianópolis: Ed. da UFSC, 1981.

${ }^{29}$ Por exemplo, em Cabral: "O elemento escravo em Santa Catarina não teve, como em outras regiões do país, largo emprego nas fainas agrícolas, só muito raramente, aqui, nelas empregado. 
Uma historiografia mais recente, no entanto, tem aprofundado a pesquisa a respeito da presença africana no estado, sua conexão com as rotas atlânticas e com a dinâmica de comércio e tráfico do Brasil imperial. ${ }^{30}$ Esta produção trouxe informações que mudaram o panorama sobre a presença africana em Santa Catarina, bem como sobre as "peculiaridades" da escravidão na província. Relativizando a definição de trabalho doméstico para as funções exercidas e mostrando o atrelamento de Santa Catarina à dinâmica das outras regiões do Império, sobretudo através das relações com o Rio de Janeiro, muitas dessas pesquisas mostram a relevância do trabalho escravo nas atividades produtivas e no comércio da Ilha e avançam nas análises sobra sua dinâmica.

Cláudia Mortari, que analisou 5.245 batismos de escravos nos livros de batismo da Freguesia de Nossa Senhora do Desterro entre 1788 e 1850, encontrou 1.138 identificados como sendo de procedência africana. ${ }^{31} \mathrm{~A}$

As principais fainas a que foram destinados prendiam-se ao trabalho nas Armações das Baleias e sua pesca e nas do tráfego marítimo, sendo numerosos os que, marinheiros, eram empregados pelos seus senhores nas embarcações que existiam na Província. Como empregados domésticos e das casas de negócio de seus senhores se ocupava a maioria - carregadores estivadores, jornaleiros, serventes, encarregados da limpeza das casas, lavadores de vidros e de casas, vendedores ambulantes, operários de várias classes, como pedreiros, carpinteiros, pintores etc. As mulheres eram, na quase totalidade, domésticas, empregando-se na cozinha, como doceiras, engomadeiras, amas etc." In Oswaldo Cabral, História de Santa Catarina, Florianópolis: Lunardelli, 1987, p. 167. E ainda, na pg.168: "Em geral, eram bem tratados, não sendo aqui, senão excepcionalmente, castigados com vigor ou desumanidade." Cabral, História de Santa Catarina. Para uma crítica dessas posições, conferir Penna, "Escravidão, liberdade e os arranjos de trabalho na Ilha de Santa Catarina".

${ }^{30}$ Conferir, principalmente, Beatriz Mamigonian, "Africanos em Santa Catarina: escravidão e identidade étnica (1750-1850)", In João Luís Ribeiro Fragoso, Manolo Florentino, Antônio Carlos Jucá Sampaio, Adriana Campos (org.), Nas rotas do império: eixos mercantis, tráfico e relações sociais no mundo português (Vitória / Lisboa / Brasília: Ed. da UFES / Instituto de Investigações Científicas Tropicais / CNPq, 2006), pp. 609-44; Henrique Espada Lima, "Sob o domínio da precariedade: escravidão e os significados da liberdade de trabalho no século XIX". Topoi, v. 6, n. 11 (2005); Daniela Sbravati, "Mulheres de (in)certa condição", Revista Mundos do Trabalho, v. 1, n. 2 (2009); Ilka Boaventura Leite (org.), Negros no sul do Brasil. Invisibilidade e territorialidade, Ilha de Santa Catarina: Letras Contemporâneas, 1996; Claudia Mortari Malavolta, "Os homens pretos de Desterro: um estudo sobre a Irmandade de Nossa Senhora do Rosário" (Dissertação de Mestrado, PUC/RS, 2000); Penna, "Escravidão, liberdade e os arranjos de trabalho na Ilha de Santa Catarina"; Rafael Cunha Scheffer; "Tráfico interprovincial e comércio de escravos em Desterro 1849-1888" (Dissertação de Mestrado, Universidade Federal de Santa Catarina, 2006).

31 Cláudia Mortari Malavolta, "Os africanos de uma vila portuária do sul do Brasil: criando vínculos parentais e reinventando identidades. Desterro, 1788/1850" (Tese de Doutorado, Pontifícia Universidade Católica do Rio Grande do Sul, 2007), p. 87. 
maioria deles era composta de homens adultos, numa proporção de 2,6 homens para cada mulher. ${ }^{32} \mathrm{O}$ predomínio de africanos adultos entre os batizados confirma uma intensificação do tráfico na vila na década de $1820,{ }^{33}$ na expectativa da proibição do tráfico a partir dos acordos entre Portugal e Inglaterra no período anterior. ${ }^{34}$

Tais resultados dialogam com as análises de Beatriz Mamigonian e Rafael Scheffer, que demonstram ter a entrada de africanos em Desterro disparado com a perspectiva da proibição do tráfico atlântico de escravos para o Brasil, seguindo a tendência de outras regiões do Brasil, nos anos anteriores à aprovação da lei de $1831 .{ }^{35}$ A partir de 1831, a entrada de africanos em Santa Catarina caiu drasticamente, porque os africanos novos foram dirigidos a centros exportadores do sudeste. ${ }^{36}$ Depois disso, a manutenção e crescimento da população escrava passou a se dar pelos nascimentos. ${ }^{37}$

Assim, ao contrário do que queriam Antero de Brito e seus pares, o tráfico interprovincial apenas teria impacto significativo na diminuição da população escrava a partir de 1870, como tem mostrado pesquisas empíricas recentes (apesar da brusca queda na entrada de adultos africanos desde a primeira proibição do tráfico atlântico de escravos em 1831). ${ }^{38}$

${ }^{32}$ Mortari, "Os africanos de uma vila portuária", pp. 87- 93.

33 Mortari, "Os africanos de uma vila portuária", p. 91.

34 Também é possível ter uma ideia de procedência dessas pessoas a partir da denominação de acordo com seus portos de embarque, como registrados no momento do batismo: entre os africanos adultos batizados, os grupos de procedência mais significativos eram os congos (267) e os cabindas (259), seguidos por moçambiques (197), costa (171), monjolo (59) e mina (55), o que aponta para a predominância, em meados do sec. XIX, de grupos da região da África Central, seguidos pela África Oriental e pela África Ocidental. Mortari, "Os africanos de uma vila portuária”, p. 91

35 Mamigonian, "Africanos em Santa Catarina"..

${ }^{36}$ Segundo Sheffer, a "presença de escravos em Santa Catarina, longe de ser desprezível, manteve sua força até meados da década de 1870". Em 1872, 10\% dos escravos de Desterro eram de origem africana e a grande maioria dos escravos crioulos era nascida no estado: " $85 \%$ eram nascidos em Santa Catarina, $2 \%$ deles vieram do Rio de Janeiro e 2\% do Rio Grande do Sul" Scheffer, "Tráfico interprovincial e comércio de escravos", p. 49.

37 Scheffer, "Tráfico interprovincial e comércio de escravos", p. 49.

38 Scheffer, "Tráfico interprovincial e comércio de escravos", pp. 40- 9; Mamigonian, "Africanos em Santa Catarina".. 


\section{Disputas políticas em torno da praça do mercado e os limites da autonomia}

É nesse contexto que o primeiro Mercado Público da cidade, criado em função da necessidade de acomodar e organizar o comércio e sociabilidades pré-existentes no local, apresenta-se como um bom lugar para observar as relações de trabalho que envolviam mulheres e homens livres, escravos e libertos. Centralizando as redes de distribuição de alimentos em Desterro, o Mercado e seus arredores possibilitavam a formação de redes de interesses e identidades, algumas vezes permitindo inserção social e econômica e, por outro lado, eram importantes definidores dos limites da autonomia de escravos e libertos e de suas expectativas de liberdade. Sua investigação nos permite também analisar as estratégias adotadas pelos poderes públicos para sanear, limpar e embelezar o espaço central e vital da cidade a partir da segunda metade do século XIX, a partir da regulamentação, fiscalização e repressão, afastando ou limitando seu o acesso àqueles grupos. ${ }^{39}$

Argumentamos aqui que essas disputas constantes pela ocupação do espaço central da cidade e em torno dos níveis de autonomia e regu-

${ }^{39}$ Como mostrou Sidney Chalhoub, as discussões parlamentares a respeito da saúde pública no Rio de Janeiro estiveram permeadas, num primeiro momento, pelas preocupações com o tráfico atlântico de escravos e o medo das revoltas escravas e, num segundo momento, com as políticas imigrantistas: conforme nos aproximamos do fim do século XIX, torna-se cada vez mais óbvio que o pensamento médico e as políticas de saúde pública no Brasil estavam profundamente informados por uma ideologia racial bastante precisa: ao menos no Rio de Janeiro e em São Paulo, tratava-se de promover o embranquecimento da população. Cf. Sidney Chalhoub, Cidade febril - cortiços e epidemias na Corte Imperial, São Paulo: Companhia das Letras, 1996. Conferir também Lilia Moritz Schwarcz, O espetáculo das raças: cientistas, instituições e questão racial no Brasil 1870-1930, São Paulo: Companhia das Letras, 1993. No caso de Desterro, para Henrique Luiz Pereira Oliveira, que trata da assistência aos expostos em Desterro, a cidade passava por transformações significativas em 1850 - momento de declínio da pratica de expor. Nos anos 1850, Desterro estaria vivendo um processo de "reelaboração das formas de sociabilidade" e gestão das condutas no espaço urbano que coincide com a edificação do prédio do mercado. Segundo ele, as elites queriam combater antigos costumes e diferenciar-se do conjunto da população." Henrique Pereira Oliveira, "Assistência aos expostos e remodelação das condutas em Desterro", in Ana Brancher e Silvia Maria Fávero Arend (orgs.), História de Santa Catarina no século XIX, Florianópolis: Ed. da UFSC, 2001, p. 223. "As ações visando promover a higiene pública eram também intervenções sobre as relações sociais, interferindo nos comportamentos e nas praticas costumeiras, definindo os padrões de conduta e usos toleráveis no espaço público." Oliveira, "Assistência aos expostos", p. 223. 
lamentação das relações de trabalho tiveram seu ponto nevrálgico nas questões referentes à construção e manutenção do Mercado Público.

Desde o início da década de 1830 nutria-se a polêmica a respeito da retirada ou da permanência das barraquinhas de venda de gêneros alimentícios na praça da Matriz - assim chamada por localizar-se em frente à igreja de mesmo nome. ${ }^{40} \mathrm{O}$ local também era conhecido como a praça do mercado, - entre a Igreja da Matriz e a praia - na qual eram desembarcados os gêneros que ali seriam vendidos ao público. A polêmica sobre a remoção das barraquinhas varou a década e mobilizou os "homens bons" de Desterro em torno de solidariedades que se revelariam incipientes divergências políticas. As barraquinhas chegaram a ser desenganadas em 1834, mas a lei não foi cumprida, ${ }^{41}$ atestando a predominância política do grupo "barraquista" nos âmbitos de decisão.

Como nos arredores da praça ficavam as lojas de importantes comerciantes da cidade, a historiografia em geral creditou a força dos "barraquistas" aos interesses desses homens em não afastar dali os atrativos que garantiam a circulação do público. ${ }^{42}$ Pouco se levou em conta a provável resistência do público consumidor ou uma possível pressão dos próprios vendedores e vendedoras em relação à referida mudança. Afinal, as quitandeiras provavelmente estendiam suas tendas e panos naquele mesmo lugar da praça desde o final do século XVIII, vendendo legumes, frutas, doces, peixe seco e comida preparada para servir aos escravos ao ganho, de modo semelhante ao que ocorria em outras grandes cidades da América portuguesa, com presença significativa de africanos, e na própria África. ${ }^{43}$

${ }^{40}$ Cabral, Nossa Senhora do Desterro, Notícia I, p. 83.

${ }^{41}$ Cabral, Nossa Senhora do Desterro, Notícia I, p. 83.

${ }^{42}$ Cabral, Nossa Senhora do Desterro, Notícia I, p. 84; Mesquita, Mercado - do mané ao turista, p. 20; Joana Pedro, Mulheres honestas e mulheres faladas - uma questão de classe, Florianópolis: Ed. da UFSC, 1994, pp. 24-5.

43 Já em 1791, o peixe era vendido nas duas bancas, além da venda na praia em frente à própria praça, aonde chegavam as canoas. AHMF, “Ofício a Presidência em 25 de março de 1844”. Registro de Correspondência, Ofícios da Câmara Municipal, 1843-1845, n. 94, Fls. 59. Como salienta Richard Graham para Salvador, na capital baiana, a ausência de um mercado central, que só seria construído em 1850, fazia com que as donas de casa dependessem dos vendedores ambulantes para suprir suas necessidades. Ali também, a maioria era de mulheres, especialmente as negras. Cf. Graham, Feeding the City, p. 35. O celeiro público foi criado em 1785, e ali se vendiam grãos, como arroz, feijão, milho e, especialmente, a farinha de mandioca. Antes disso, as embarcações ancoravam na praia para vender a farinha, como em Desterro. Graham, Feeding the City, pp. 92-3. 
O historiador catarinense Osvaldo Cabral ensaia uma explicação para o processo de ocupação da praia pelas quitandeiras e pombeiros e, posteriormente, a pendenga em torno da criação do prédio do Mercado Público:

Ponto de convergência desses produtores, que diretamente vendiam os gêneros que traziam, era para ali que se viam atraídos os moradores, a fim de mais barato adquirir as necessidades de sua mesa - a farinha, os legumes, as caças, os peixes.

Mais tarde foram abertos os caminhos, facilitando o acesso a Vila por terra, de certas partes, sem que contudo as canoas deixassem de frequentar a praia costumeira. Aos poucos surgiram os produtos de feitura doméstica, e então, as quitandeiras, que eram mais quituteiras do que outra coisa e que, devendo passar longas horas ao sol, junto à praia, cuidaram de abrigar-se, e às suas panelas e balaios, debaixo de toldos de esteiras e de restos de velas inservíveis das embarcações.

$[\ldots]$

Foi assim que quiosques e barraquinhas (para os quais haviam evoluído os toldos das quitandeiras) e bancas de peixe reuniram-se no local mais central e acessível da Vila. É certo, também, que não se sabe com exatidão quando as tendas, os abrigos ao acaso, levantados pelos vendedores e quitandeiras, transformaram-se em 'propriedade da nação'. Certamente o governo teria auxiliado para que fossem construídas barraquinhas permanentes, mais ou menos uniformes, e buscado posteriormente ressarcir-se do emprego de capital mediante a cobrança de alugueres. ${ }^{44}$

Tudo indica que Oswaldo Cabral estivesse correto quando afirmou que ali já existiam barraquinhas - onde também se vendia comida preparada para os trabalhadores de ganho - antes da construção e funcionamento do prédio do Mercado Público. Muitas dessas "casas de quitanda" eram geridas por africanas, como, por exemplo, a preta Maria Calabá, a preta forra Joanna Prates ou Joaquim Ignácio da Silva, que pagavam imposto de cinco mil réis para permanecer na praça do mercado em $1851^{45}$.

Para Cabral, o problema era justamente essa oficialização das

${ }^{44}$ Cabral, Nossa Senhora do Desterro, Noticia I, pp. 79-80.

45 AHMF, Livro Caixa: Receita e despesa da Câmara Municipal (1851-1852). 
barraquinhas, que enfeiavam a praça central da cidade. Mas, ainda pior, era seu aluguel ser permitido a pessoas que, em ofício da Câmara Municipal, foram qualificadas de "imorais e até mesmo a escravos" 46 . Nas palavras deste historiador:

Aí é que foi o mal pois um aglomerado de biscateiros e de ambulantes, reunidos numa espécie de feira-livre, que poderia ser dissolvida a qualquer momento por uma simples disposição da Câmara, adquiriu uma inesperada estabilidade. A nação lhes construiu os barracos - eles, biscateiros, os alugaram. Agora, para removê-los, seriam necessários muita força e muito engenho. ${ }^{47}$

Para ele, como para muitos outros, a disputa na década de 1840 estava clara: era a falta de visão e a sobreposição dos interesses pessoais de homens com certo poder ao interesse comum da cidade que movia o grupo que se opunha à derrubada das barraquinhas e a expulsão da gente desqualificada dali. Do outro lado, estavam aqueles que pensavam no bem comum, no embelezamento e no progresso da capital da província, procurando limpar e "moralizar" seu espaço central.

A polêmica em torno da construção do mercado, portanto, materializava disputas entre projetos de intervenção pública, de saneamento e de embelezamento. Isso fica bastante explícito em 1838, quando dois engenheiros apresentaram proposta de projeto para a construção de um Mercado Público entre a Rua do Livramento e a do Ouvidor (atuais Trajano e Deodoro respectivamente). ${ }^{48} \mathrm{Na}$ apresentação do projeto o engenheiro Sepúlveda Everard intencionava "acabar com a sujeira da praia, construindo uma "solida muralha", e arborizar o terreno ganho, transformando-o num "ponto aprazível de reunião das famílias". ${ }^{49}$ Para o engenheiro

Ele [o Mercado] preenche três fins muito importantes: a saúde, a como-

${ }^{46}$ Cabral, Nossa Senhora do Desterro, Notícia I, pp. 80-1.

${ }^{47}$ Cabral, Nossa Senhora do Desterro, Notícia I, p. 81.

48 APESC - Ofício de Patrício Antônio de Sepúlveda Everard, Major dos Engenheiros a João Carlos Pardal, Presidente da Província - 21/2/1938, Livro dos Engenheiros, Vol.1 (18301845), pp. 68-9.

49 APESC - Ofício de Patrício Antônio de Sepúlveda Everard, Major dos Engenheiros a João Carlos Pardal, Presidente da Província - 21/2/1938, Livro dos Engenheiros, Vol.1 (18301845), p. 84. 
didade pública, e o avultado acréscimo de rendimento para os cofres do Município. Circunscrita a venda dos gêneros comestíveis a certo espaço fechado fácil no qual seria fácil fiscalizar sua qualidade, peso, medida e preço. ${ }^{50}$

Assim, a função de saneamento incluía a retirada das barraquinhas e dos escravos e libertos para que as "famílias" pudessem ocupar aquele espaço. Além disso, sendo o espaço fechado e delimitado, ficaria mais fácil controlar a qualidade e o preço dos alimentos e, portanto, a ação dos atravessadores. Finalmente, um dos pontos bastante atrativos para a municipalidade era a arrecadação que esse controle possibilitaria, obrigando todos que ocupassem o local a pagar os devidos impostos. ${ }^{51}$

Foi como mais um passo para controlar o fornecimento de carne, além das questões sanitárias, que, em 1840, a presidência da província consultou a Câmara Municipal sobre o melhor lugar para um matadouro, ${ }^{52}$ e iniciou um plano para sua construção. ${ }^{53}$ Não por acaso, no mesmo período davam-se as primeiras tentativas de levar a cabo um projeto para o Mercado Público, que fazia parte de um plano mais geral de regular a venda de gêneros alimentícios e os impostos que isso rendia. Mas o projeto não foi levado a diante.

Em 1845 as barraquinhas, nas quais eram vendidos os gêneros, foram finalmente retiradas da praça, e transferidas para as proximidades do Forte de Santa Bárbara, mais tarde sede da Capitania dos Portos

${ }^{50}$ APESC - Ofício de Patrício Antônio de Sepúlveda Everard, Major dos Engenheiros a João Carlos Pardal, Presidente da Província - 21/2/1938, Livro dos Engenheiros, Vol.1 (18301845), mas o projeto não foi levado adiante.

51 No decorrer do século XIX, as atribuições de regulamentação e fiscalização passaram à câmara municipal e seus fiscais, mas essas atribuições, além da luta contra o açambarcamento e pelo "preço justo", estiveram em disputa com os poderes provinciais e a própria população. Sobre essas disputas em Desterro conferir: Fabiane Popinigis, "'Em benefício do povo': o comércio de gêneros em Desterro no século XIX", in Regina Xavier (org.), Escravidão e Liberdade: temas, problemas e perspectivas de análise, Alameda (no prelo). Para uma análise mais geral dessas disputas, conferir: Magnus Roberto de Mello Pereira, "Almuthasib Considerações sobre o direito de almotaçaria nas cidades de Portugal e suas colônias", Revista Brasileira de História, v.21, n. 42 (2001) pp. 365-95.

52 AHMF -"Registro do ofício dirigido ao exmo. Presidente da Província". Registro da Correspondência da Câmara Municipal, 1840/1843, n. 85.

53 Cabral, Nossa Senhora do Desterro. Notícia II. Florianópolis; Ed. Lunardelli, 1972, pp. 29-30. 
e desde 2001 a Fundação Cultural de Florianópolis. ${ }^{54}$ O motivo era a visita do imperador d.Pedro II e da imperatriz dona Thereza Christina à cidade, em passagem para a província vizinha de São Pedro do Rio Grande do Sul. Desembarcaram em outubro de 1845. O plano era ficarem cinco dias, que se estenderam a 27, durante os quais também visitaram diversos locais na província, deixando as autoridades provinciais e municipais em polvorosa. ${ }^{55}$ A família real passou por Desterro também na volta da viagem, e em fevereiro de 1846, após a partida da realeza para a Corte, voltaram à carga os "barraquistas", querendo que o comércio de gêneros retornasse ao local onde antes estava, ou seja, a praça da Matriz, contrariando grupo dos "vinagristas" (assim chamados porque queriam que a feira permanecesse nas proximidades da Ponte do Vinagre). ${ }^{56}$

Desenvolveu-se, a partir desta questão, acirrada disputa entre os "barraquistas" e os "vinagristas" dentro da própria Câmara Municipal, visando à liderança política no pleito, que em geral é descrita pelos historiadores como o início da história dos partidos na cidade. $\mathrm{O}$ debate em torno da construção do Mercado Público foi de tal modo importante e centralizador das atenções dos políticos de Desterro que acabaram definindo as duas lideranças (então chamadas de "judeus" e "cristãos"), que posteriormente constituiriam, respectivamente, os partidos Liberal e Conservador no município. ${ }^{57}$ A vitória dos cristãos - que queriam a construção do prédio na praça da Matriz - teria fortalecido os conservadores, que derrotariam os liberais nas eleições de 1847. Joana Pedro chama a atenção para esses debates, sugerindo a emergência de uma elite comercial que enfrentava o poder provincial através da Câmara Municipal, e segundo ela, impunha seus interesses. ${ }^{58}$

O Marechal Antero Ferreira de Brito, vindo de fora da cidade e

54 Joana Pedro; Nas tramas entre o público e o privado - a imprensa de Desterro no século XIX, Florianópolis: Editora da UFSC, p. 23; Veiga, Florianópolis, memória urbana, pp. 195 -97.

55 Mesquita, Mercado - do mané ao turista, pp. 22-3.

${ }^{56}$ Cabral, Nossa Senhora do Desterro, Notícia I, p. 85; Mesquita, Mercado - do mané ao turista, pp. 22-3.

57 Cabral, História de Santa Catarina, p. 146; Pedro, Nas tramas entre o público e o privado, pp. 24-5.

58 Pedro, Nas tramas entre o público e o privado, p. 24. 
da província, tendo experiência em cargos de comando no Rio de Janeiro e no Rio Grande do Sul, ${ }^{59}$ tinha outras relações e uma visão diferente do que deveria ser o saneamento e o embelezamento de uma capital do Império do Brasil. ${ }^{60}$ Irritou-se com a pendenga e decretou que todos pudessem vender seus gêneros livremente em qualquer local, exceto... na praça do Palácio. ${ }^{61}$ Como se pode imaginar, foi obrigado a voltar atrás dias depois, tamanha a grita geral. ${ }^{62}$

Em maio de 1846 a Assembleia Provincial aprovou lei que ordenava a construção do prédio do Mercado Público no local mais conveniente, sem, contudo, determiná-lo. ${ }^{63}$ Em 1847, a Câmara pedia ao governo provincial que aprovasse a construção de três barracões na dita praça. ${ }^{64}$ Antero Ferreira de Brito opôs-se terminantemente ao projeto. A Câmara voltou a reclamar o empreendimento e o presidente da província fincou pé, explicando que o considerava de mau gosto e oposto ao que queria fazer: construir a Alfândega e uma grande rampa ao longo da praia para facilitar a chegada dos passageiros e mercadorias, principalmente o pescado. ${ }^{65}$ Insinua, finalmente, a ideia da construção de um prédio de mercado:

Façamos a rampa, com que já me vou ocupar, depois do que não duvidarei que alli então se construa uma praça de mercado, porém que seja segundo o plano que a Presidência apresentar, e que será correspondente à beleza da praça. A Câmara Municipal há de conformar-se com isso. ${ }^{66}$

59 Cabral, História de Santa Catarina, pp. 140-41.

${ }^{60}$ Antero Ferreira de Brito havia feito carreira militar e exercido postos de comando no executivo da Corte. Quando ocupou o cargo de presidente da província de Santa Catarina, entre 1841 e 1848, foi responsável pela formulação de um audacioso plano de intervenção no espaço urbano da pequena Desterro. Dentre as intervenções sugeridas por ele, estava a construção de um cais em frente à praça do palácio, murada ao longo de toda a linha do litoral, com rampas e cais e a execução de um aterro próximo à Rua do Menino Deus. Cf. Beatriz Mamigonian; "Em nome de beleza, comodidade e benefício público: um projeto de intervenção urbana para Desterro no século XIX." Geosul, v. 14, n. 28 (1999), pp. 179-88.

${ }^{61}$ Cabral, Nossa Senhora do Desterro, Notícia I, p. 86

${ }^{62}$ AHMF, Registro de Correspondência: Ofícios da Câmara Municipal. 1843-1845, n.94, p. 176 (verso).

${ }^{63}$ Cabral, Nossa Senhora do Desterro, Noticia I, p. 87.

${ }^{64}$ APESC - Ofícios da Câmara Municipal ao Presidente da Província, 6/2/1947, fls. 1.

65 Fala que o Presidnte da Província de Santa Catharina, o marechal de campo Antero José Ferreira de Brito dirigiu á Assembleia Legislativa da mesma província no ato da abertura de sua sessão ordinária em $1^{\circ}$ de março de 1847 . Cidade do Desterro: Typ. Provincial, 1847, pp. 9-12. Disponível em http://brazil.crl.edu/bsd/bsd/934/, acessado em 27/1/2011.

${ }_{66}$ Fala que o Presidnte da Província de Santa Catharina, o marechal de campo Antero José Ferreira 
O tom é imperativo, e deixa claro que se o governo da província tinha de arcar com as despesas da construção, havia também de fazerlhe o plano, que deveria ser seguido à risca pela municipalidade. Desta feita o presidente escreveu longa explicação advertindo a Assembleia Provincial sobre a inconveniência de erguerem-se os três barracões que os vereadores e o presidente da Câmara Municipal haviam solicitado para a venda de pescado, farinha, hortaliças e grãos e para a carne verde (a carne fresca, em oposição ao charque). Argumentava ele que aquilo daria muito má ideia sobre "nosso bom gosto", relembrando a recente existência de uma banca de peixe na mesma praça. Esta lhe incomodara a vista e continuava a lhe atazanar a memória: "o peixe fresco de mistura com a carne, e tudo calcado aos pés dos pretos e pretas quitandeiras". ${ }^{67}$ Assim, Antero de Brito pretendia evitar que se incorresse novamente no mesmo erro, estragando a vista daquela praça que era por ele tão bem considerada, e da qual ele tanto se havia ocupado quando tratara da reforma da igreja, da criação de dois pequenos jardins, da plantação de árvores e da construção do edifício público da Tesouraria. Também desejava ele que, no "edifício a que impropriamente se chamava Palácio" - e que ele estava cuidando de embelezar e aumentar - pudesse futuramente reunir-se a Assembleia Provincial. ${ }^{68}$

Obcecado com o "aformoseamento" e "saneamento" da capital da província, contrapôs-se às intenções da Câmara Municipal de construir "barracões" na praça da Matriz. Reiterou, entretanto, que se empenharia em propiciar as condições para a construção de um Mercado

de Brito dirigiu á Assembleia Legislativa da mesma província no ato da abertura de sua sessão ordinária em $1^{\circ}$ de março de 1847. Cidade do Desterro: Typ. Provincial, 1847, pp. 9-12. Disponível em http://brazil.crl.edu/bsd/bsd/934/, acessado em 27/1/2011.

${ }^{67}$ Fala que o Presidnte da Província de Santa Catharina, o marechal de campo Antero José Ferreira de Brito dirigiu á Assembleia Legislativa da mesma província no ato da abertura de sua sessão ordinária em $1^{\circ}$ de março de 1847 . Cidade do Desterro: Typ. Provincial, 1847, pp. 9-12. Disponível em http://brazil.crl.edu/bsd/bsd/934/, acessado em 27/1/2011.

68 Tal era seu apreço pela praça que, ao deixar o cargo ele recomenda expressamente ao seu sucessor: "a conservação do Palácio da Presidência e de tudo quanto contem; a conservação do aceite da praça em frente do Palácio, do plantio do arvoredo; da conservação dos dois pequenos jardins em frente da igreja matriz; estas coisas todas têm estado a cargo da Presidência que de bom grado procurava aformoseamento da melhor praça que tem esta capital." Relatório do Presidente de província Antero de Brito que deixa o cargo para o vice, Severo Amorim do Valle em 1848, p. 14. Disponível em http://brazil.crl.edu/bsd/bsd/u903/, acessado em $27 / 1 / 2011$. 
Público que atendesse às necessidades de compra e venda da população, mas que também embelezasse o local. ${ }^{69}$

O caso é que, meses depois, em outubro de 1847, Antero de Brito continuava irritado com as indecisões dos vereadores da Câmara Municipal e escreveu que, tendo juntado grande quantidade de pedras e aterro no local a ser construída a rampa ao longo da praia da praça da Matriz, nada mais seria feito até que a Câmara entrasse em consenso. ${ }^{70}$ Bem se vê que ele tentou liberar a praça daquele amontoado de todo o tipo de gente, dos cheiros e consistências do pescado, da carne e dos restos que eram jogados ao mar bem em frente. Se nisso falhou, o presidente seguiu com o plano para a construção do prédio do mercado: antes que deixasse o cargo, em dezembro de 1848 a Assembleia Provincial finalmente aprovou uma lei autorizando, com recursos da província, o financiamento da edificação do dito Mercado Público, que seria posteriormente passado à administração municipal. ${ }^{71}$

O projeto para a construção do prédio do mercado ficou a cargo do engenheiro João de Souza Mello e Alvim. ${ }^{72}$ Em março do ano seguinte Severo Amorim do Valle, que então ocupava o cargo de presidente da província, informava, animado, sobre o avanço da construção e a necessidade de mais verbas para concluí-la. Antônio Ferreira Pinto, seu sucessor, deixou documentado o desgosto com a escolha do local: “... esse edifício no lugar em que se acha colocado, na Praça Principal desta Capital, é um epigrama à civilização, e ao bom gosto". ${ }^{73}$

Quem certamente estava feliz da vida era João Pinto da Luz,

69 Fala que o Presidnte da Província de Santa Catarina, o marechal de campo Antero José Ferreira de Brito dirigiu á Assembleia Legislativa da mesma província no ato da abertura de sua sessão ordinária em o $1^{\circ}$ de março de 1847. Cidade do Desterro: Typ. Provincial, 1847, pp. 9-12. Disponível em http://brazil.crl.edu/bsd/bsd/934/, acessado em 37/1/2011.

70 APESC - Registro da Correspondência Oficial com Câmaras Municipais da Província (18461848), p. 212.

71 Relatório do Presidente de Província, 26 de dezembro de 1848, p. 5. Disponível em http:// brazil.crl.edu/bsd/bsd/u903/000001.html, acessado em 27/1/2011.

72 Relatório do Presidente de Província, 26 de dezembro de 1848, p. 5. Disponível em http:// brazil.crl.edu/bsd/bsd/u903/000001.html, acessado em 27/1/2011.

73 Relatório do Presidente de Província Antônio Ferreira Pinto, 1849. Rel. em que o Exmo. Sr. Dr. entregou a Presidência da Província de Santa Catarina ao exmo. Sr. Dr. Severo Amorim do Valle, $3^{\circ}$. Vice-presidente, pp. 16-7. Disponível em http://brazil.crl.edu/bsd/bsd/u903/, acessado em 27/1/2011. 
político, armador e negociante com loja de ferragens na Rua Augusta, que hoje leva seu nome. Líder dos cristãos, Pinto esteve, desde o início da discussão, interessado na construção do Mercado naquele local. ${ }^{74} \mathrm{~A}$ ele coube a administração da obra e chegou a emprestar dinheiro, juntamente com outros, para o término da construção. ${ }^{75}$ Foi assim que, para desgosto de alguns, regozijo de outros e desconfiança de muitos, a obra foi lentamente adiante.

Ao findar o ano de 1850 estava pronto o prédio, no alinhamento da Rua do Príncipe (atual Conselheiro Mafra), na parte de baixo da praça da Matriz, junto ao mar. ${ }^{76} \mathrm{O}$ primeiro Mercado Público de Desterro foi oficialmente inaugurado em janeiro de 1851, quando o presidente da província, João José Coutinho passou as chaves ao presidente da Câmara Municipal, Clemente Antônio Gonçalves. ${ }^{77}$

O Mercado era um prédio retangular térreo, com portas nos quatro lados, que davam acesso ao espaço onde os vendedores alugavam "casinhas" nos nichos cobertos, ou no espaço junto às colunas. Eram 12 "casinhas" com portas e janela e paredes divisórias entre elas, mais quatro bancas de carne e as de peixe. As bancas da carne tinham balcão e mesas de picar, com grades de madeira e piso de tijolos, quatro ganchos fortes para pendurar a carne, seis balanças de 15 quilos e uma de 58,8 quilos. As bancas e o gradeamento eram pintados a óleo. No centro

74 João Pinto da Luz chefiava os "cristãos" (associados, posteriormente, aos conservadores) na disputa pelo local de construção do Mercado. Cf. Joana Pedro. Nas tramas entre o público e o privado, pp. 24-5. Cf. também Cabral, Nossa Senhora do Desterro. Noticia I, pp. 88-9.

75 Fala que o Presidente de Província, o marechal de campo Antero José Ferreira de Brito dirigiu à Assembleia Legislativa da mesma Província, por ocasião da abertura de sua sessão ordinária, em $1^{\circ}$. De março de 1848, p. 5. Disponível em http://brazil.crl.edu/bsd/bsd/ 932/, acessado em 27/1/2011.

76 Ao final, seu custo subiu a 12:297\$230 réis, ou mais do que três vezes em relação ao orçamento inicial. A renda do mercado ficou hipotecada até abril de 1854 em função do pagamento da dívida. In: Fala que o Presidente da Província de Santa Catarina o Exmo. Snr. Dr. João José Coutinho dirigiu a Assembleia Legislativa da mesma Província por ocasião da abertura de sua sessão ordinária em $1^{\circ}$ de Março de 1853, Cidade do Desterro: Typ. do Conservador, 1853. Disponível em: http://brazil.crl.edu/bsd/bsd/940/, acessado em 27/1/2011.

77 Para uma descrição detalhada do exterior e interior do mercado, com as casinhas, as bancas de carne e peixe, o pátio e os corredores cf. Fala que o Presidente de Província Dr. João José Coutinho dirigiu à Assembleia Legislativa da mesma Província, por ocasião da abertura de sua sessão ordinária, em $1^{o}$ de março de 1851, fls. 16, 17 e 18. Disponível em http:// brazil.crl.edu/bsd/bsd/938/, acessado em 27/1/2011. 
havia um pátio descoberto, onde existia também um poço de água para uso dos negociantes e do público. ${ }^{78}$

Neste pátio central os lavradores depositavam suas mercadorias com exceção da carne verde e do peixe, ou lenha e carvão - para vendêlas ao público em pequenas medidas até as nove horas da manhã. Depois deste horário os pombeiros poderiam arrematá-las. Era permitido aos lavradores que ali ficassem com o que restara para vender até duas horas da tarde, quando o guarda da praça, encarregado de manter a ordem, os retirava. ${ }^{79}$ As posturas definiam como pombeiros aqueles que compravam mercadorias diretamente dos produtores e depois revendiam pelas ruas da cidade ou de porta em porta, àqueles que não fossem adquiri-las no Mercado Público. ${ }^{80}$

O artigo do regulamento que determinava o horário mínimo para o repouso dos gêneros visava permitir que todos pudessem ter acesso aos produtos sem o acréscimo dos intermediários. ${ }^{81}$ Entretanto, o pátio não oferecia espaço suficiente para todos os lavradores e muitos continuavam, junto com seus víveres, legumes, ovos e hortaliças, à mercê do sol e da chuva. Embora isso tenha sido posteriormente constatado e reclamado através dos jornais, parece que era algo já esperado, pois um dos artigos do regulamento do Mercado Público define que o guarda

${ }^{78}$ O historiador Osvaldo Cabral descreve o aspecto externo do mercado da seguinte maneira: “... um bloco de quatro faces, retangular com uma porta em cada lado, com quatro pares de olhos de boi nas faces mais externas, e dois nas menores. Os cantos eram ornados com um jarrão de alvenaria e a platibanda do lado que fazia frente para a praça era enfeitada com um tímpano bastante simples sobre a porta principal. O telhado era baixo, achatado, de telhas goivas." Cf. Cabral, Nossa Senhora do Desterro - Notícia I, pp. 78-9.

79 APESC - Regulamento do Mercado Velho. Ofícios da Câmara Municipal a Presidência da Província, 1850, Fls. 120-126.

80 Assim, o Artigo $1^{\circ}$ definia que: "Toda pessoa que compra (ainda mesmo que por comissão) sejam quais forem os gêneros alimentares e comestíveis nacionais ou estrangeiros por lugares públicos como sejam ruas, praças, estradas, marinhas, a bordo de navios ancorados em portos de mar ou rios sem que por esse comercio pague algum outro imposto". Também cabiam na definição de pombeiro, como explica o Artigo $5^{\circ}$ "aqueles que vendessem carne de vaca sem que a rês tenha sido morta no matadouro publico, e outras carnes em tabuleiros pelos lugares acima designados". AHMF - Projeto de Postura submetido pela Câmara à Presidência da Província para aprovação em Julho de 1850; Registro da correspondência da Câmara Municipal dessa cidade a Presidência da Província, 1848-1853, n.109, fls.115.

81 APESC - Regulamento do Mercado Público, Art.46. Ofícios da Câmara Municipal a Presidência da Província 1850, Fls 120-126. 
permitiria àqueles que tivessem gêneros que poderiam se estragar ocupassem um lugar na varanda. ${ }^{82}$

Cada um dos vãos entre as colunas do Mercado, localizados entre o pátio central e a varanda, era dividido em dois espaços, e cada um desses "espaços de quitanda" poderia ser ocupado por duas pessoas. Pagava-se 1\$200 réis mensais pelo aluguel e os idealizadores certamente contavam com a presença das escravas quitandeiras ali, considerando o baixo preço e a possibilidade de dividir o aluguel com alguém (600 réis para cada). O regulamento era bastante claro neste sentido: enquanto o art. $13^{\circ}$ definia que "as casas só poderão ser alugadas a pessoas livres" o art. $30^{\circ}$ esclarecia que os lugares de quitanda "poderão ser alugados a pessoas livres, e a escravos, com licença por escripto de seus senhores", o que demonstra a frequência e o costume destes arranjos de trabalho. ${ }^{83}$

\section{Pombiando e vivendo de quitandas}

No primeiro ano de existência do prédio do Mercado Público, entre julho de 1850 e junho de 1851 , das 63 pessoas que pagaram imposto de pombeiro ou de quitanda, 37 eram homens e 26 eram mulheres. Dentre os homens, 14 estavam pagando imposto para um escravo (2) ou uma escrava (12) venderem seus produtos. Um deles era Pedro Congo Luiz. Aqui a referência à condição desses homens e mulheres era mais explícita e nos permite maior informação sobre eles: dentre as 26 mulheres pagando imposto, três delas eram pretas libertas e 13 eram escravas. Entre as mulheres que pagavam imposto de pombeira (3.200 réis mensais) encontravam-se as "pretas forras" Rita de Jesus, Ana Maria e Catharina. ${ }^{84}$ Entre as escravas, duas pagavam para vender, as outras tinham os impostos pagos pelas proprietárias. ${ }^{85}$

Entre julho e dezembro de 1854, dos 23 espaços de quitanda ocupados no Mercado Público, houve uma média de 20 mulheres e três

\footnotetext{
82 APESC - Regulamento do Mercado Público, Art.58o.

83 APESC - Regulamento do Mercado Público, Art.58o.

${ }^{84}$ AHMF - Livro caixa: Receita e Despesa da Câmara Municipal 1851-1852.

${ }^{85}$ AHMF - Livro caixa: Receita e Despesa da Câmara Municipal 1850-1851.
} 
homens ocupando o posto. Entre elas, sete carregavam nomes que faziam menção a sua origem africana, como Simôa Mina, Anna Mina, Maria Mina, Josefa Caçange, Esperança Cabinda, Luiza Cabinda, Zeferida Calabá e, finalmente, Luiz Congo, pagando para uma forra vender. ${ }^{86}$

Neste mesmo espaço de tempo, 30 pessoas pagaram imposto de pombeiro, dos quais 16 homens e 14 mulheres, entre elas Luiza Cabinda, e Anna Mina, Zeferida Calabá (corruptela de Calabar), Josefa Caçange e as pretas Esperança Cabinda e Margarida, depositando nos cofres da Câmara Municipal, cada uma, a soma mensal de 3.200 réis. $^{87}$

Já no livro referente aos impostos pagos no segundo semestre de 1859 e no primeiro de 1860 , de 40 pessoas pagando imposto de pombeiro e mascate, apenas uma era mulher: a preta liberta Maria. ${ }^{88}$ Os livros referentes à década de 1860 confirmam o deslocamento das mulheres dessas funções, reservando a elas o lugar de quitandeiras pelas ruas de Desterro.

Esses dados nos mostram, em primeiro lugar, uma esmagadora maioria de mulheres quitandeiras atuando no Mercado Público. Além disso, os nomes registrados apontam para uma significativa presença de trabalhadoras de origem africana. Fica claro também que algumas delas (Esperança Cabinda, Josefa Caçange e Zeferida Calabá) exerciam suas atividades dentro e fora do prédio do Mercado, pombiando e vendendo quitandas, talvez contando com alguém para uma das funções. Muitas dessas mulheres, portanto, acumulavam funções e exerciam atividades dentro e fora do mercado.

Entre os mascates, de um total de 14 pagamentos feitos entre 1854 e 1855, cinco foram realizados por mulheres e nove por homens. Aqui não há referências explicitas à condição social ou a cor dos envolvidos e envolvidas, ${ }^{89}$ com exceção do caso da preta liberta Ana da Costa Pereira, que pagava imposto mensal de 6.400 sobre "mascates". ${ }^{90}$ Se o pombeiro negociava gêneros alimentícios, o mascate era definido como

\footnotetext{
AHMF - Livro caixa: Receita e Despesa da Câmara Municipal 1854-1855.

AHMF - Livro caixa: Receita e Despesa da Câmara Municipal 1854-1855.

AHMF - Livro caixa: Receita e Despesa da Câmara Municipal 1859-1860.

AHMF, livro caixa n.139 - Receita e despesa da Câmara Municipal 1854-1855.

90 AHMF, livro caixa n.139 - Receita e despesa da Câmara Municipal 1854-1855. O sobrenome

Da Costa poderia designar, de forma geral, a procedência africana (da costa da África).
} 
aquele que vendia gêneros não alimentícios, nacionais ou estrangeiros, e para isso pagava impostos. ${ }^{91}$

Percebe-se a diversidade de termos utilizados para classificar a situação social do vendedor ou vendedora em questão ("preta forra", "liberta", "escrava", ou ainda sem referência, o que leva a crer que era pessoa livre), associados a uma quantidade relevante de sobrenomes que carregavam referências às diferentes "nações" africanas a que estavam associadas aquelas pessoas, denominadas a partir das regiões de origem do tráfico escravo e aqui ressignificadas.

Além da grande presença de mulheres, esses dados revelam uma gama de situações e arranjos de trabalho que escravos e libertos estabeleciam com seus proprietários: a autonomia de trabalhar no Mercado Público, ou fora dele, vendendo quitandas ou pombiando (a serviço da senhora, do senhor, ou para si próprios); as relações que estabeleciam com alguém em situação semelhante para dividir os vãos entre as colunas; a possibilidade de, com algum acúmulo a partir das vendas, comprar sua própria alforria e, finalmente, pagar o imposto para que alguém trabalhasse para si; redes de interesses e identidades que possibilitavam a inserção e o trânsito nesses locais e posições.

No caso de Desterro, outros trabalhos mostraram que mulheres viúvas ou solteiras dependiam do trabalho de escravos e escravas de ganho para seu sustento, ${ }^{92}$ numa relação de dependência mútua que permitia a estes últimos certa autonomia e algum poder de barganha. ${ }^{93}$ Assim, o fato de que algumas escravas pagassem seus próprios impostos (ao invés do registro do nome da proprietária pagando para uma escrava vender) também era significativo, apontando para certo nível de autonomia conquistado por elas. A partir daí, não era impossível que acumulassem pecúlio para a compra da própria alforria. ${ }^{94}$

91 AHMF - Registro da correspondência da Câmara Municipal dessa cidade a presidência da província, 1848-1853, n.109, fls.115.

92 Pedro, Mulheres honestas, mulheres faladas.

93 Sbravati, "Mulheres de (in)certa condição".

94 Sobre a capacidade das mulheres africanas de acumularem a partir do trabalho com o comércio, conferir Sheila de Castro Faria, "Mulheres forras: riqueza e estigma social", Revista Tempo, v.5, n.9 (2000). Sobre a proeminência mina nesse tipo de comércio, ver Carlos Eugênio Líbano Soares e Flávio dos Santos Gomes, Negras minas no Rio de Janeiro: gênero, nação e 
Foi o caso de Maria Mina, que trabalhava como quitandeira no Mercado Público, onde alugava, com outra pessoa, um dos vãos entre as colunas em 1855. Era escrava do mascate Luis de Santanna Carpes, de quem conseguiu a alforria em 1860, com empréstimo do Capitão Clemente Gonçalves, que era presidente da Câmara Municipal de Desterro à época da inauguração do prédio do mercado, em 1851. É possível que esta Maria Mina seja a mesma que, alforriada, continuou trabalhando como quitandeira no mercado, ${ }^{95}$ chegando, em 1883 , a acumular pecúlio para libertar outro escravo. ${ }^{96}$ Se esse for o caso, Maria Mina foi uma das que aproveitou o momento favorável, em torno da década de 1850, e soube aplicar seu capital político e econômico para manter certa posição no comércio de alimentos no contexto menos favorável das décadas seguintes.

Entretanto, à reconhecida liberdade de ir e vir dessas mulheres no ambiente urbano, já muito reafirmada pela historiografia, ${ }^{97}$ os poderes públicos procuravam impor limitações. $\mathrm{O}$ artigo $41^{\circ}$ do Código de Posturas de 1845 proibia escravos com quitanda de andarem nas ruas ou estarem nas praças após o toque de recolher, ficando sujeito o recalcitrante à multa de mil réis ou 24 horas de prisão, caso o senhor não pagasse a multa. ${ }^{98} \mathrm{~A}$ determinação era semelhante àquela feita pelo artigo $35^{\circ}$ do mesmo Código, segundo o qual "vadios, escravos" não poderiam permanecer nas vendas, tabernas ou casas de quitanda mais do que o tempo necessário pra comprar e vender. ${ }^{99}$ Proibia-se também ao vendeiro de consentir ajuntamentos de escravos, toques, danças e vozerios. $\mathrm{O}$ art. 38 do dito Código de Posturas proibia "os ajuntamentos de escravos, ou libertos para formarem batuques; bem como os que

trabalho urbano no século XIX, in Mariza de Carvalho Soares (org.), Rotas atlânticas da diáspora africana: da Baía do Benin ao Rio de Janeiro, Niterói: Ed.UFF, 2007.

95 AHMF, Livro caixa n.183, 1867-1868.

96 Arquivo do Fórum Municipal de Florianópolis, 1 ${ }^{\text {a }}$. Vara de Família: Cx.02 de 1883, n.199

97 Luiz Carlos Soares, "Os escravos de ganho no Rio de Janeiro do século XIX", Revista Brasileira de História, n. 16 (1988); Mary C. Karash, A vida dos escravos de no Rio de Janeiro (1808-1850), São Paulo: Companhia das Letras, 2000; Roberto Guedes Ferreira, "Autonomia escrava e (des)governo senhorial na cidade do Rio de Janeiro da primeira metade do século XIX”, in Manolo Florentino (org.), Tráfico, cativeiro e liberdade - Rio de Janeiro, séculos XVII-XIX, Rio de Janeiro: Civilização Brasileira, 2005.

98 AHMF - Código de Posturas da Câmara Municipal de Desterro (1845), art. $41^{\circ}$.

99 AHMF - Código de Posturas da Câmara Municipal de Desterro (1845), art.35. 
tiverem por objectos os supostos reinados africanos, que, por festas, costumão [sic] fazer". ${ }^{100}$

Além daqueles que das vendas no Mercado Público tiravam seu sustento, mulheres e homens negros, livres, libertos ou escravos ao ganho misturavam-se a trabalhadores brancos pobres, fazendo compras para si ou para seus proprietários ou patrões. Entretanto, aos escravos e escravas só era permitido frequentar o interior do Mercado se estivessem a serviço de seus patrões e patroas. Nesse caso, que fizessem rapidamente as compras: "não poderão demorar-se por mais tempo que o necessário para efetuá-las. O Guarda do Mercado, ou o Fiscal logo que observarem que eles ali se conservam sem intenção de comprar os farão [sic] sair." 101

Os escravos que trabalhavam no Mercado com respectiva licença dos proprietários não podiam nele pernoitar, condição aberta a outros, como os locatários das casinhas (pessoas livres) e suas famílias (além do próprio guarda). A permissão também se estendia "aos donos, consignatários, caixeiros de carne e peixe todas as vezes que à hora de fechar-se o Mercado ainda tenham porção de qualquer d'esses gêneros nas bancas para venderem no dia seguinte". ${ }^{102}$ Esclarece-se também que nenhum quitandeiro ou quitandeira poderia pernoitar ali. ${ }^{103}$ Além desses, mais artigos destinam-se a tentar restringir a presença dos negros e negras no interior do Mercado, inclusive proibindo música, jogos e danças, ou "qualquer outro divertimento". ${ }^{104}$

Sobre o movimento de exclusão de que eram objeto os escravos e libertos e de sua determinação em permanecer no centro do processo de produção e distribuição de gêneros em Desterro, o caso de Joanna Prates pode ser revelador. Em 1851, ela pagava cinco mil réis de imposto para manter sua casa de quitanda na praça do mercado. Após o início do funcionamento do prédio do Mercado Público, Joanna não mais aluga-

\footnotetext{
${ }^{100}$ Cf. Jaime José dos Santos, "Entre a diversão e as proibições: as festas de escravos e libertos na Ilha de Santa Catarina", in Beatriz Mamigonian e Joseane Zimmerman (orgs.), História diversa: africanos e afrodescendentes em Santa Catarina (no prelo).

${ }^{101}$ APESC - Regulamento do Mercado Público, Art.53.

${ }^{102}$ APESC - Regulamento do Mercado Público, Art.65․

${ }^{103}$ APESC - Regulamento do Mercado Público, Art. $32^{\circ}$.

${ }^{104}$ APESC - Regulamento do Mercado Público, Art.51 ${ }^{\circ}$.
} 
va uma casa de quitanda: passou a ocupar um intervalo de coluna dentro do prédio do Mercado, dividido com Joana Rosa. ${ }^{105}$ Até aí, nada de extraordinário, ela estava acompanhada de muitas outras na mesma condição. Mas no ano seguinte, de agosto de 1855 a julho de 1856, a dita "preta forra" Joanna, foi mais longe, e alugou uma casinha do Mercado em seu próprio nome. Como não sabia escrever, um tal Jacintho Francisco assinou o contrato por ela em agosto, repetindo o ato em janeiro do ano seguinte, e alugando por mais seis meses a casinha n. 3 pelo mesmo preço de 6.600 réis. ${ }^{106} \mathrm{O}$ contrato semestral era feito através de leilão e por isso os preços de aluguel eram diferentes entre si.

É significativo que Joanna tenha sido a locatária que mais caro pagou, dentre o grupo de nove pessoas que alugaram as casinhas do Mercado quando renovou o contrato no primeiro semestre de 1856. Além de ser a única ex-escrava (provavelmente africana) a constar nos contratos, é também a única mulher. Desta vez, os preços do aluguel mensal variaram entre 5.000 e 6.600 réis, tendo ela sido a única a pagar o preço máximo para aquele período. Entretanto, a partir de junho de 1856 Joanna não mais aparece na lista de pagamento, e desta feita todos os locatários pagaram os mesmos cinco mil réis pelo aluguel mensal de suas respectivas casinhas. Não sabemos o motivo pelo qual Joanna não renovou seu contrato, nem o porquê de ela ter pago o aluguel mais caro entre os contratantes.

Não havia, porém, mecanismo legal que impedisse Joanna de alugar a dita casinha, pois a proibição do regulamento do mercado não se referia aos libertos, mas aos escravos. Essa quitandeira liberta tivera sua barraquinha na praça, antes da construção do Mercado Público, e pouco tempo após sua inauguração conseguira se manter por dois semestres consecutivos como comerciante numa das casinhas do Mercado. Entretanto, perderia esse espaço na segunda metade da década de 1850 , tendo que se conformar em ocupar, dali para frente, um dos vãos entre as colunas do Mercado ao lado de escravos e escravas.

No caso dos escravos, havia determinações legais para impedir seu acesso a determinadas posições no comércio, dentro e fora do Mer-

${ }_{105}$ AHMF - Receita e despesa da Câmara Municipal 1854-1855, Livro caixa, n.139.

${ }^{106}$ AHMF - Termos de arrematação das casinhas do Mercado, 1855-1880, fls. 5 e 6. 
cado Público: o artigo 128 do Código de Posturas de Desterro, de 1845, proibia que pessoas de condição escrava ocupassem a posição de caixeiro em qualquer casa comercial. Construído o Mercado Público, seu regulamento interditava aos escravos vender carne ou pescado, a não ser que estivessem diretamente subordinados aos próprios "carniceiros" ou pescadores: "só poderão ser vendidos pelos próprios carniceiros, pescadores, dizimeiros, seus consignatários ou caixeiros sendo pessoas livres, e os escravos dos próprios pescadores ou carniceiros." 107

Observamos, portanto, que ao crescente controle que se tentava impor à população de escravos e libertos, aliavam-se os esforços de regulamentação para a venda dos gêneros alimentícios. Expressa tanto no regulamento do mercado como no Código de Posturas, estava a preocupação com os atravessadores e com a qualidade dos alimentos ou a venda de comida estragada, atenção especial à carne verde, que foi objeto de reiterados esforços de controle. ${ }^{108}$

O pescado e, sobretudo, a carne verde, tinham status especial. A carne só podia ser vendida nas bancas destinadas a ela, e não podia entrar retalhada, ou seja, deveria ser cortada - com serrote, e não com machado - no próprio Mercado Público. ${ }^{109} \mathrm{O}$ carniceiro deveria pesá-la à vista do consumidor, sob pena de multa. Assim que terminassem suas vendas, carniceiros e pescadores eram obrigados a lavar e assear suas bancas. ${ }^{110}$ Caso fosse advertido pelo guarda por ter vendido carne estragada, incorreria em multa e a carne seria lançada fora, o mesmo valendo para o pescado. ${ }^{111}$

A julgar pelas proposições da Câmara Municipal à presidência da província em 1850, muitos pombeiros e negras de tabuleiro escapavam às deliberações, apesar de toda a restrição a respeito da carne. Afinal, um edital desse ano dizia que deveria se sujeitar ao imposto de pombeiro todo aquele que vendesse carne de vaca ou outras carnes em tabuleiro pelas ruas, praças, estradas, marinhas, a bordo de navios an-

\footnotetext{
${ }^{107}$ APESC - Regulamento do Mercado Público, Art. $22^{\circ}$.

${ }^{108}$ Cf. Fabiane Popinigis, "Em benefício do povo".

${ }^{109}$ APESC - Regulamento do Mercado Público, Art. $18^{\circ}$.

${ }^{110}$ APESC - Regulamento do Mercado Público, Art. $21^{\circ}$.

${ }^{111}$ APESC - Regulamento do Mercado Público, Art. $23^{\circ}$.
} 
corados em portos de mar ou rios, sem que a rês tivesse sido morta no matadouro público. ${ }^{112}$ A necessária licença para a venda dos gêneros deveria ser apresentada ao fiscal do distrito, que poria o visto no verso. ${ }^{113}$ A tentativa de reiterar essas proibições se repete nas décadas seguintes, ${ }^{114}$ tendo o secretário da Câmara chegado a afirmar, em ofício ao fiscal, que a arrecadação estava diminuindo. ${ }^{115}$

Escravos e libertos procuravam burlar as tentativas de regular suas redes de sociabilidade e suas possibilidades econômicas. Assim, como o regulamento do mercado os proibia de "andarem dentro da Praça pretos de ganho e mendigos", e determinava 24 horas de cadeia aos que desobedecessem a advertência do guarda do Mercado Público, ${ }^{116}$ fora dele, nos seus arredores, as negras continuavam a fazer comida para vender, fritando peixe e cozinhando mocotó. ${ }^{117}$ Também continuariam, durante um longo tempo, com seus negócios de quitanda ainda que as posturas procurassem restringi-la a lugares específicos, como o próprio Mercado, sujeito a controle e taxação. $\mathrm{O}$ fato de que os editais e posturas estipulando multas para vários tipos de burla e descumprimento a essas determinações continuassem a ser publicadas ao longo da segunda metade do século XIX evidencia a frequência com que ocorriam.

112 “Art. $5^{\circ}$ - É também classificado Pombeiro, e sujeito ao imposto de 3.200 , e as penas do Artigo $1^{\circ}$, aquele que vender carne de vaca sem que a rês tenha sido morta no matadouro público, e outras carnes em tabuleiros pelos lugares acima designados", in AHMF, Projeto de Postura apresentado pela Câmara Municipal a Presidência da Província para aprovação em 24 de Julho de 1850. Registro da Correspondência da Câmara Municipal desta Cidade à Presidência da Província. 1848 a 1853, n. 109, fls. 115.

${ }^{113}$ AHMF, Projeto de Postura apresentado pela Câmara Municipal a Presidência da Província para aprovação em 24 de Julho de 1850. Registro da Correspondência da Câmara Municipal desta Cidade à Presidência da Província. 1848 a 1853, n. 109, fls. 115.

${ }^{114}$ Por exemplo, em 1878, outro ofício da secretaria da câmara municipal aos fiscais informa de acordo com resoluções anteriores - os procedimentos e a obrigatoriedade de pagamento de impostos e licenças pelos pombeiros, sob pena de multa. O fiscal deveria, como anteriormente, lançar o visto no talão. Em AHMF -"N109: Aos Fiscaes do Município", Livro 189 Registro Geral de Correspondência da Câmara Municipal de Desterro.

115 "Nota-se um grande decrescimento no número de contribuintes dessa Câmara, urge que Vossa Senhoria empregue os meios ao seu alcance para evitar o exercício de qualquer indústria ou profissão das que pagão impostos por indevida não habilitação devendo para isto a apresentação do conhecimento que prove o pagamento do imposto respectivo usando as faculdades que pelo Código de Posturas são permitidas", in AHMF, "Circular para os Fiscais das Freguesias", n.52, 1873. Livro de Registro n.189.

${ }^{116}$ APESC, Regulamento do Mercado Público, Art.52.

${ }^{117}$ Cabral, Nossa Senhora do Desterro, Notícia II. 
As posturas revelavam determinados desejos dos legisladores no momento de sua aprovação e publicação, e certamente tinham seu efeito. Entretanto, seu descumprimento era corrente. Requerimentos em geral e a correspondência trocada entre a Câmara Municipal e diversas autoridades, bem como as circulares citadas acima, são indicadores mais seguros das disputas cotidianas. Em especial, as frequentes circulares da secretaria da Câmara os fiscais das freguesias, procurando apoiar-se nas determinações existentes para reiterar questões como a proibição aos batuques, a circulação de escravos após determinado horário, os ajuntamentos de negros em casas comerciais e a burla aos impostos sobre a venda de alimentos, mostram que os africanos e seus descendentes continuavam a ocupar espaços centrais da cidade.

\section{A reconfiguração do espaço central da cidade}

Como vimos, a praça do mercado público de Desterro foi, até 1860, importante fator para concretizar expectativas de liberdade e autonomia de africanos e descendentes em luta pela sobrevivência cultural e econômica. Contudo, construído o prédio do Primeiro Mercado, ficou cada vez mais difícil para eles, como para a nossa conhecida Joanna Prates, conseguirem se estabelecer como comerciantes. Se em 1855 uma mulher, negra e forra fora capaz de alugar uma daquelas casinhas ainda que por pouco tempo, isto não se repetiria nos anos seguintes. Assim, pronto o primeiro Mercado Público, escravos(as) e libertos(as) passaram a ocupar lugares específicos para a venda de quitanda: os vãos entre as colunas do prédio.

Os primórdios da história de sua construção correspondem à proibição do tráfico de escravos em 1831 e às revoltas escravas das décadas seguintes, que amedrontaram autoridades e proprietários na Bahia e no Sudeste, passando pelos primeiros ensaios nos debates sobre a substituição do braço escravo no Império brasileiro. $\mathrm{O}$ ano de sua conclusão, em 1850, é o mesmo da abolição do tráfico atlântico. Sua história é parte integrante das progressivas tentativas de controle sobre a população escrava, livre e liberta. $\mathrm{O}$ avançar da segunda metade do século XX viu o aprimoramento da ideologia de higiene e sua influência nas polí- 
ticas públicas, o acirramento em torno das tentativas de regulamentação, sobretudo, da fiscalização e a arrecadação de impostos sobre a circulação e venda de gêneros alimentícios. Por outro lado, o aumento dos preços de terras e escravos e a crescente racialização e diminuição do espaço de ascensão social, correspondia uma escalada na utilização, por esses homens e mulheres, da própria legislação para alcançar a liberdade ou conquistar mais espaços. ${ }^{118}$

Por muito tempo, o desejo que tinham os legisladores e governantes de que os africanos e seus descendentes desaparecessem dos projetos de construção da nação pareceram ter-se tornado realidade em Santa Catarina, ao menos no caso dos livros de história e de outros tipos de registro, ${ }^{119}$ que por tanto tempo escolheram esquecer a presença de Maria Rosa, Thereza, Faustina e tantas outras mulheres que alugavam os lugares de quitanda no Mercado Público.

Homens como Antero de Brito e seus pares rejeitavam a ideia de incorporação dos descendentes de africanos à sociedade de Santa Catarina. Quando elaboravam e executavam projetos, baixavam decretos e assinavam leis para limpar, embelezar as regiões centrais da cidade, tinham também a intenção de excluir escravos e libertos, africanos e seus descendentes de determinados espaços e limitar sua conquistada autonomia. Cada vez mais, pela segunda metade do século XIX adentro, estariam imbuídos de ideologias raciais que permeavam suas decisões sobre as políticas públicas a serem adotadas, com suas preocupações voltadas para a imigração de europeia.

Entretanto, um olhar mais atento ao Mercado Público e às áreas centrais da cidade de Desterro, revela que um grande número de trabalhadores(as) livres, libertos(as), escravos(as) atuavam nas redes

\footnotetext{
${ }^{118}$ Robert Slenes, “A 'Great Arch' Descending: Manumission Rates, Subaltern Social Mobility and Slave and Free(d) Black Identities in Southeastern Brazil, 1791-1888", in John Gledhill and Patience Schell (orgs), Rethinking Histories of Resistance in Brazil and Mexico (Durham, NC, forthcoming); Hebe Mattos, "Raça e cidadania no crepúsculo da modernidade escravista no Brasil", in Keyla Gringberg e Ricardo Salles (orgs.), O Brasil imperial - Vol.III (1870-1889) (Rio de Janeiro: Civilização Brasileira, 2009); Joseli Mendonça, Cenas da Abolição - escravos e senhores no Parlamento e na Justiça, São Paulo: Ed. Fundação Perseu Abramo, 2001.

${ }^{119}$ Cf. Leite (org.), Negros no sul do Brasil.
} 
de comércio e distribuição de alimentos, mostrando que os africanos e seus descendentes lutavam como podiam para seguir adiante mantendo suas relações familiares, suas redes de sociabilidade e comércio para conquistar melhores condições de vida. Evidencia-se também, a progressiva diminuição dos sobrenomes que faziam referência às nações africanas no final da década de 1860: assumiam outros sobrenomes, ou envelheciam e morriam, deixando seus descendentes. Mas, além disso, o espaço configurava-se de outras formas, como se percebe pela diminuição da significativa participação feminina nas funções de pombeiro e mascate constatada até meados da década de 1850. Nos livros de registro da década de sessenta, não há mais a condição social ou a referência racial associada ao nome do contribuinte.

Ainda assim, casos como o de Maria Mina, africana que em Desterro utilizou suas aptidões de comerciante para ocupar um lugar dentro Mercado e comprar sua própria alforria e a de outro escravo, mostram que negros como ela se inseriram também nos meandros do pequeno comércio e do crédito da cidade para garantir seu sustento ou até mesmo acumular alguns bens. A história dela e de outras, bem como a do preto liberto Lourenço, que tinha uma pequena propriedade de frente para o mar, moinhos de moer grãos e pequenas canoas para transportar a produção, mostram que ainda há muito que contar sobre as trajetórias de africanos e africanas em Santa Catarina, sua participação nas redes de produção e distribuição de alimentos e serviços e suas estratégias de resistência econômica e cultural. Finalmente, ao observar as disputas em torno da praça do mercado e da circulação de gêneros em Desterro a partir das relações entre seus agentes, evidencia-se a conexão da província às outras regiões do Brasil imperial, sobretudo através do Rio de Janeiro, numa dinâmica que a conecta ao próprio mundo atlântico, através do comércio de escravos e das experiências que aqueles homens e mulheres trouxeram de seu continente de origem e as que viveram na travessia atlântica e na nova terra, entre a escravidão e a liberdade.

Texto recebido em 18/5/2011 e aprovado em 1/3/2012 


\title{
Resumo
}

Este artigo trata da construção, em 1851, do primeiro Mercado Público de Desterro (atual Florianópolis), espaço centralizador do comércio de gêneros e circulação de pessoas. A dinâmica em torno do mercado é aqui utilizada para investigar as disputas políticas relacionadas à ocupação deste espaço central da cidade, as expectativas de liberdade e autonomia de homens e mulheres africanos e seus descendentes, e as possibilidades e limites para realizá-las. $\mathrm{Na}$ primeira metade do século XIX, as mulheres africanas tinham atuação proeminente no comércio de rua e na própria praça do mercado, tanto como quitandeiras quanto como pombeiras e mascates, configuração que sofreu transformações no decorrer da segunda metade do século XIX, com a significativa diminuição da presença de homens africanos e de mulheres em geral, tanto dentro do Mercado Público quanto nas funções de pombeiro e mascate.

Palavras-chave: Mercado Público - Desterro - expectativa de liberdade - mulheres - africanos - quitandeiras

\begin{abstract}
This article examines the construction, in 1851, of the first Public Market in the city of Desterro (now Florianópolis), an important center for the commercialization of goods and the circulation of people. The social dynamics of this market are used here in contextualizing the expectations of freedom by African men and women and their descendants, as well as their degree of autonomy and their possibilities - and limits - in achieving it. During the first half of the $19^{\text {th }}$ century, African women played a prominent role as street vendors and in the market place itself, but this configuration changed over the second half of the century, when the presence of African men and women decreased, as did that of their descendants, in the Public Market as well as in the rest of the city as street vendors.
\end{abstract}

Key-words: Desterro - Public Market - expectation of freedom - women Africans - street vendors 